\title{
Dyke-Davidoff-Masson syndrome: unusual cause of hemiplegic cerebral palsy
}

\author{
Indar Kumar Sharawat, Renu Suthar, ${ }^{\oplus}$ Naveen Sankhyan
}

Pediatric Neurology Unit, Department of Pediatrics, Post Graduate Institute of Medical Education and Research, Chandigarh, India

Correspondence to Dr Renu Suthar, drrenusuthar@gmail.com

Accepted 24 March 2019

\section{DESCRIPTION}

A 2-year-old-girl presented with recurrent episodes of right focal seizures. She had a history of prolonged febrile status epilepticus at 15 months, and subsequently had two more right focal motor seizures at 18 months of age. She was noted to have a paucity of movements of the right half of the body subsequent to the second seizure. She was born to non-consanguineous parents and had an uneventful antenatal and perinatal period. Her development was age appropriate. Her family history was unremarkable. On examination, she had normal anthropometric parameters, right upper motor type of facial palsy and right hemiparesis. She could speak two-word sentences and could walk with support. There were no asymmetric findings on physical examination. A clinical possibility of hemiconvulsion-hemiplegia-epilepsy (HHE) syndrome or Rasmussen encephalitis was considered.

An interictal electroencephalogram revealed frequent spikes and slow waves originating from the left frontotemporal region. A neuroimaging showed left hemispheric atrophy with thickening of the ipsilateral calvarium (figure 1). A diagnosis of Dyke-Davidoff-Masson syndrome (DDMS) was made, and the child continued on antiepileptic drugs. Physiotherapy and occupation rehabilitation was initiated.

DDMS was first described in 1933 by Dyke and colleagues. Classically, it presents with hemiparesis, focal or generalised epilepsy, facial asymmetry, varying degree of mental retardation, behavioural abnormalities, hemiatrophy and sensory disturbances. The two forms of the disease are congenital and acquired. ${ }^{1}$ Congenital form presents in the neonatal period or infancy and considered secondary to vascular insult in the antenatal or

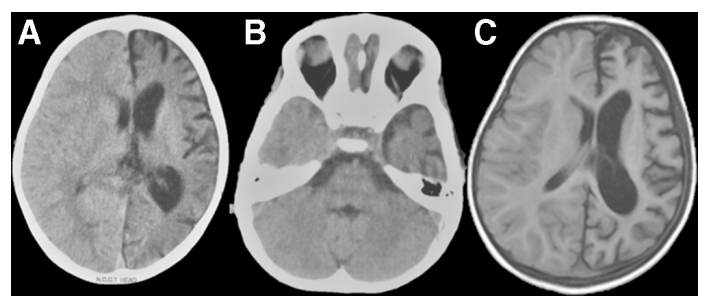

Figure 1 Neuroimaging of the child with DykeDavidoff-Masson syndrome. Axial sections of CT $(A, B)$ and $M R I(C)$ of the brain showing atrophy of left hemisphere with prominent sulci, atrophy of left caudate and ipsilateral dilatation of lateral ventricles. Note the thickening of ipsilateral calvarium $(A-C)$ and hyperpneumatised left mastoid sinus (B). neonatal period. The acquired form is consequent to haemorrhage, trauma and ischaemic injury to the brain. ${ }^{1}$ The age of symptom onset depends on the timing of cerebral insult and the extent of brain parenchymal involvement. ${ }^{2}$ The typical neuroimaging shows hemiatrophy, thickened ipsilateral calvarium, dilatation of ventricles and hyperpneumatisation of mastoid or frontal sinuses. Hypoplastic middle cranial fossa; thalamic and cerebellar peduncles atrophy; widening of the Sylvian fissure; cortical sulci and hypoplasia of lentiform nucleus are additional features. ${ }^{3}$ The index child had the congenital form of DDMS, characterised by hemiatrophy of entire cerebral hemisphere and focal epilepsy. The congenital form of DDMS with focal status epilepticus should be differentiated from HHE syndrome and Rasmussen encephalitis, supported by lack of typical MRI features, the presence of thickened calvaria and hyperpneumatised sinuses and relative non-progressive focal deficits.

\section{Learning points}

- Dyke-Davidoff-Masson syndrome is an unusual cause of hemiplegic cerebral palsy.

- Unilateral cerebral atrophy, thickened ipsilateral calvarium, dilatation of ventricles and hyperpneumatisation of mastoid or frontal sinuses are typical findings in neuroimaging.

- Congenital form is considered secondary to vascular insult in the antenatal or neonatal period.

Contributors IKS: Patient management, literature review and initial draft of the manuscript preparation. RS: Patient management, critical review of the manuscript for important intellectual content and final approval of the version to be published. NS: Clinician-incharge, critical review of the manuscript for important intellectual content and final approval of the version to be published.

Funding The authors have not declared a specific grant for this research from any funding agency in the public, commercial or not-for-profit sectors.

Competing interests None declared.

Patient consent for publication Parental/guardian consent obtained.

Provenance and peer review Not commissioned; externally peer reviewed.

\section{REFERENCES}

1 Karuppiah S, Rodgman C, Lombard J. Dyke-Davidoff-Masson syndrome in postcerebral malaria. J Child Neurol 2009;24:487-90.

2 Zawar I, Khan A, Sultan T, et al. An unusual cause of status epilepticus. Neurosciences 2015;20:385-7.

3 Gökçe E, Beyhan M, Sade R. Radiological imaging findings of DykeDavidoff-Masson syndrome. Acta Neurol Belg 2017;117:885-93. 
Images in...

Copyright 2019 BMJ Publishing Group. All rights reserved. For permission to reuse any of this content visit https://www.bmj.com/company/products-services/rights-and-licensing/permissions/

BMJ Case Report Fellows may re-use this article for personal use and teaching without any further permission.

Become a Fellow of BMJ Case Reports today and you can:

- Submit as many cases as you like

- Enjoy fast sympathetic peer review and rapid publication of accepted articles

Access all the published articles

- Re-use any of the published material for personal use and teaching without further permission

For information on Institutional Fellowships contact consortiasales@bmjgroup.com

Visit casereports.bmj.com for more articles like this and to become a Fellow 